EESTI NSV TEADUSTE AKADEEMIA TOIMETISED. 29. KOIDE

KEEMIA, 1980, NR. 3

ИЗВЕСТИЯ АКАДЕМИИ НАУК ЭСТОНСКОП ССР, ТОМ 29

ХИМИЯ. 1980, №3 3

A. MUREL

удК 678.746 .52

\title{
SYNTHESIS OF IMPROVED AND INEXPENSIVE CARRIER AMPHOLYTES FOR ISOELECTRIC FOCUSING
}

\author{
(Presented by O. Kirret)
}

Theoretical requirements for the structure of improved carrier ampholytes (CAs) are presented. It is shown that a high amino-group content in one ampholyte molecule provides high buffer capacity and high conductivity in the focusing system. Since pentaethylene hexamin (PEHA) is the most $\mathrm{N}$-saturated amine available, the increase in the amino-group content in one CA molecule is achieved by coupling polyethylene polyamines (PEPA) by cross-linking agents in pairs.

A simple and inexpensive synthetic procedure is presented. Some physico-chemical properties of the new CAs are described. $\pi$-complex between unsaturated bond and more than one amino-group is suggested to explain gel formation during synthesis.

\section{Introduction}

Isoelectric focusing (IEF) and isotachophoresis (ITP) are the methods of great, if not the greatest, resolving power in the separation of amphoteric molecules. However, wide application of these methods, particularly on a preparative scale, is restricted mainly by considerable cost of commercial CAs $\left[{ }^{1-4}\right]$.

Several authors $\left[{ }^{4-6}\right]$ have synthesized «home-made» CAs in their laboratories following Vesterberg's $\left.{ }^{[7}\right]$ general idea of reaction between PEPA and acrylic acid - principle of LKB ampholine [8].

It is tempting to operate always with fresh CAs since they can polymerize with time, giving coloured admixtures. The procedure mentioned $\left.{ }^{8}\right]$ enables quick and simple synthesis of suitable fresh CAs. Other patents describing the synthesis of CAs (for instance, $\left[{ }^{9}\right]$ ) are too complicated and expensive to be reproduced routinely in laboratories.

Aminoacids which are focusing broadly due to their high mobilities $\left[{ }^{10}\right]$ can cause a flattening of $\mathrm{pH}$ gradient formed by $\mathrm{CAs}$ at $\mathrm{pH}$ of their pIs. These «separators» were used $\left[{ }^{2}\right]$ to produce shallow $\mathrm{pH}$ gradients, which enables better separation of proteins. $\mathrm{pH}$ gradients created only by «separators», i. e. by low molecular amphoteric (and nonamphoteric) buffers have been investigated [11]. It is surprising that there are only few publications dealing with separators and IEF in buffers.

CAs obtained from protein hydrolyzates were discussed by Righetti et al. [ $\left.{ }^{4}\right]$, page 335 .

IEF without $\mathrm{CA}$ in borate-polyol systems [ $\left.{ }^{12}\right]$ provides good separation of proteins comparable if not identical with parallel runs of IEF with LKB Ampholines [ $\left.{ }^{13}\right]$. 
Not only the high cost of commercial CAs and the need for fresh CAs stimulate the synthesis of «home-made» ampholytes; some authors were dissatisfied with the performance of the commercially available CAs $\left.{ }^{5}\right]$. Catsimpoolas $\left[{ }^{14}\right]$ underlined the urgent necessity of synthesis of improved CAs that will provide more uniform conductance, concentration and viscosity distribution. These were the reasons for the work represented here.

\section{Theory}

In the presence of all other properties in common (stability, high solubility in water at their pIs, low UV absorption, etc.), CAs with higher buffer capacity have better separation properties $\left[{ }^{15-17}\right]$. Svensson has shown $\left[{ }^{16}\right]$ that both buffer capacity $-d \theta / d(\mathrm{pH})$ of ampholyte molecule

$$
-d \theta / d(\mathrm{pH})=(2 \ln 10) /\left(2+10^{(\mathrm{pI}-\mathrm{pK} \cdot)}\right)
$$

and electric conductivity (dependent on the extent of protolysis $\alpha$ in isoelectric point)

$$
\alpha=2 /\left(2+10^{(\mathrm{pI}-\mathrm{pK} \cdot)}\right)
$$

have their maxima as seen in eqs (1) and (2) when $\left(\mathrm{pI}-\mathrm{pK} \mathrm{K}_{+}\right)$is minimal. Here $\mathrm{pK}_{+}$represents the dissociation constant of the amino-group nearest to $\mathrm{pI}$.

The greater the amino-group content in ampholyte molecule, the closer are their $\mathrm{pKs}$ spaced, and the smaller is an average $(\mathrm{pI}-\mathrm{pK}+)$. Let us consider CAs synthesis to proceed from PEPA and acrylic acid. Let us suppose that:

1. All amino-groups of PEPA have the same acitivity in reaction with acrylic acid.

2. The amino-group can react with not more than one acrylic acid.

3. $\mathrm{pKs}$ of amino-groups and $\mathrm{pK}$ of acrylic acid do not change when acrylic acid is attached.

4. $\mathrm{pKs}$ of amino-groups in resulting CAs are uniformely distributed in the range from $\mathrm{pK}=10$ ( $\mathrm{kK}$ of the most basic amino-group) to $\mathrm{pK}=3$ (pK of acrylic acid).

Now one can calculate the $\left(\mathrm{pI}-\mathrm{pK}_{+}\right)$alternation with an increase in the amino-group content.

Table $t$

Theoretical dependence of $\left(\mathrm{pI}-\mathrm{pK}_{+}\right)$on amino-group content $m$ in one $\mathrm{CA}$ molecule. $\mathrm{pI}=\left(\mathrm{pK}_{-}+\mathrm{pK}_{+}\right) / 2$

\begin{tabular}{c|ccccccccccc}
\hline$m$ & 2 & 3 & 4 & 5 & 6 & 8 & 12 & 15 & 20 & 25 & 30 \\
\cline { 2 - 9 } $\mathrm{pI}-\mathrm{pK}+$ & 1.75 & 1.16 & 0.87 & 0.70 & 0.58 & 0.44 & 0.29 & 0.23 & 0.17 & 0.14 & 0.12
\end{tabular}

Rilbe showed $\left[{ }^{18}\right]$ that $\left(\mathrm{pI}-\mathrm{pK} \mathrm{K}_{+}\right)$must never be smaller than $\lg 2$ so that maximum buffer capacity (b. c.), from eg. 1 is $(\ln 10) / 2$. Curve 1 (Fig. 1) describes the relative b. c. dependent on $m$ which has its maximum when $\left(\mathrm{pI}-\mathrm{pK} \mathrm{K}_{+}\right)$is $\lg 2$. If we assume that $(\mathrm{pI}-\mathrm{pK}+)$ approaches its maximum asymptotically, the same dependence will be described by 2 (Fig. 1). Conductivity of CAs will follow the same dependence. 
Fig. 1. Theoretical dependence of buffer capacity of carrier ampholytes in their isoelectric point on amino-group content. For explanation see the text.

The theoretical conclusion that CA buffer capacity increases with an increase in the number of amino-groups is supported by practical results $[4,7]$ : only PEHA possessed the satisfactory properties. CAs from lower amines gave gaps in conductivity

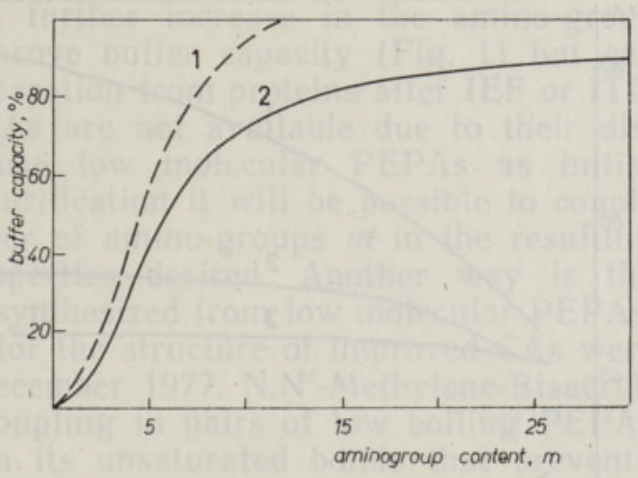
and buffer capacity with overheating in these zones due to the greater value of $(\mathrm{pI}-\mathrm{pK}+) . \mathrm{pH}$ gradient was not linear due to the deficiency of $\mathrm{CA}$ in some $\mathrm{pH}$ zones and due to unequal $\mathrm{CA}$ properties in different $\mathrm{pH}$ zones. It could be expected that molecules with more than 6 amino-groups would provide better separation properties. But such amines are not available, since they boil above their decomposition temperature. The crude product contains too many coloured admixtures to be purified by charcoal as done for PEHA [ $\left.{ }^{2}\right]$ or CAs [ ${ }^{3}$ ] purification. PEHA distillation is the most cumbersome operation during $\mathrm{CA}$ synthesis $\left[{ }^{4}\right]$. By the way, both «Ampholine» and «Servlyt» [9] are synthesized from PEHA and lower amines. Let us assume that pI of CAs synthesized according to the presented model decreases linearly from $\mathrm{pH}=10 \quad(i=0)$ to $\mathrm{pH}=3 \quad(i=m)$ with an increase in acid residue content $i$ in $\mathrm{CA}$ molecule:

$$
\mathrm{pI}=10-7 i / m \text {. }
$$

Let us consider CAs with $i / m$ ratio in the range from 0 to $1 / 3$ to be basic, from $1 / 3$ to $2 / 3$ - neutral, and from $2 / 3$ to 1 - acidic CAs.

If initial nitrogen : carboxyl ratio of reagents $M / I$ is $2 / 1$ as usual, products with different $i / m$ ratio can be obtained, so that:

$$
\Sigma i / \Sigma m=I / M \text {. }
$$

For instance, CAs from ethylene diamine ( $m$ is 2 ) can be: 1) basic product, $i / m=0$, one possible combination without coupled acid residues, 2) neutral product, $i / m=1 / 2$, two possible combinations with one acid residue on one from two nitrogens and 3) acidic product, $i / m=1$, one combination with both nitrogens occupied by acid residues. Total number of combinations in this example is 4 . It is easy to show that a total number of possible combinations for different PEPAs can be expressed

Table 2

Total number of possible combinations of PEPA wiht acrylic acid residues

\begin{tabular}{c|ccccccc}
\hline$m$ & 2 & 4 & 6 & 8 & 10 & 12 & 20 \\
\hline $\begin{array}{l}\text { Number of combinations } \\
\text { Number of known }\end{array}$ & 4 & 16 & 64 & 256 & 1024 & 4096 & $10^{6}$ \\
\hline $\begin{array}{l}\text { structural isomers } \\
\text { strum }\end{array}$ & 1 & 4 & 10 & &
\end{tabular}




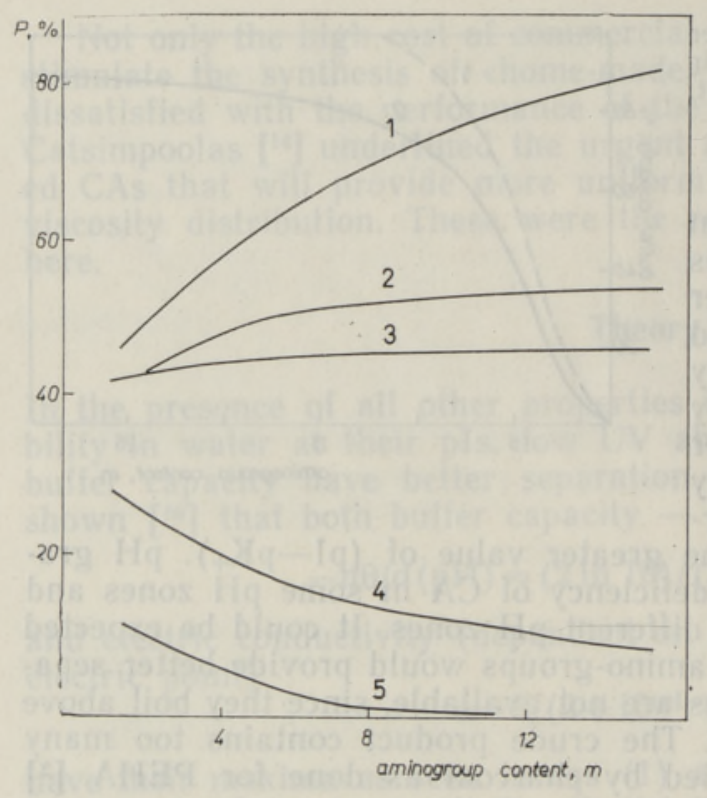

Fig. 2. Theoretical dependence of the yield of a certain $\mathrm{pH}$ range CAs on amino-group content in one CA molecule. Reagent proportion: $M / I=2 / 1,1$ - represents the yield of neutral products, 4 yield of acidic and basic products. Reagent proportion: $M / I=3 / 1$; 2 - represents the yield of neutral products, $3-$ basic products, 5 acidic products.

Reagent proportion: $M / I=1.5 / 1$, 2 - represents the yield of neutral products, 3 - acidic products, 5 - basic products

as $2^{m}$, Table 2 . Real number of combinations must be much greater since every PEPA has its structural isomers and since primary amino-groups can react with two acrylic acid molecules.

The number of possible combinations of $C_{m}^{i}$ for a certain $i / m$ ratio product in the considered reaction can be calculated:

$$
C_{m}^{i}=\frac{m !}{i ! \cdot(m-i) !} \text {. }
$$

The possibility $p$ of a certain $i / m$ ratio (i. e., the specific weight of a certain pI fraction of product) is obtained by multiplication of $C_{m}^{i}$ at the possibility of considered $i / m$ ratio divided by total number of combinations:

$$
p=\frac{m !}{i ! \cdot(m-i) !} \cdot\left(1-\frac{I}{M}\right)^{m-i} \cdot\left(\frac{I}{M}\right)^{i} \cdot 2^{-m}
$$

The specific weight of acidic, basic, and neutral product as a function of $m$ and of reagent $M / I$ ratio can be calculated (Fig. 2).

\section{Discussion}

Calculations revealed that the separation properties of synthetic CAs (dependent on buffer capacity, conductivity, and isomers number) are improved with an increase in the amino-group content in one CA molecule (Tables 1, 2; Fig. 1). Moreover, the high $m$ content can provide a shallow pH gradient CA synthesis (Fig. 2). Really, the practice of IEF has shown that the most critical zone of $\mathrm{pH}$ gradient is a «zone of pure water» ( $\mathrm{pH}$ ca. from 5 to 8 ). Outside this zone the conductivity is sufficient due to the high mobilities and conductivity concentrations of $\mathrm{H}^{+}$and $\mathrm{OH}^{-}$ions. Hence, it is very desirable to cover this zone by CAs of increased conductivity. According to previous article [ $\left.{ }^{10}\right]$, this could be done by increase in the molecular weight of pI $5-8$ («neutral») CAs, other CAs being of lower molecular weight.

CAs synthesized from amines with $m$ about $8-12$ seem to be suffi- 
cient for practical needs since a further increase in the amino-group content does not considerably improve buffer capacity (Fig. 1) but can hamper the large CA molecules separation from proteins after IEF or ITP.

Since higher than PEHA PEPAs are not available due to their distillation impossibility, one can use low molecular PEPAs as initial material for CA synthesis. After purification it will be possible to couple PEPAs in pairs so that the number of amino-groups $m$ in the resulting molecule corresponds to the properties desired. Another way is the coupling in pairs of CA molecules synthesized from low molecular PEPAs.

These theoretical requirements for the structure of improved CAs were formulated in our laboratory in December 1977. N, N'-Methylene-Bisacrylamide (BIS) was suggested for coupling in pairs of low boiling PEPAs due to the great distance between its unsaturated bonds that prevents intramolecular sewing. We decided to pend our results [ $\left.{ }^{19}\right]$, and in May 1979 priority was registered. In August 1979 Charlionet et al. published their article $\left[{ }^{20}\right]$. These authors also used BIS and other cross-linking agents to improve the properties of CAs synthesized by them from mixtures containing triethylene tetramine (TETA), tetraethylene pentamine (TEPA) and «No 6» PEPA. The used ratio (PEPA): (crosslinking agent) was $6: 1$, while we used $2: 1$ ratio to couple CAs in pairs. Nevertheless, the Charlionet et al. results are very promising, mainly due to the high content of already suitable «No 6» PEPA. These authors [ $\left.{ }^{20}\right]$ explained the improvement of CAs properties only by an increase of diversity of ampholyte species. However, the main reason for it, as shown above, is another one. Nevertheless, we have independently synthesized similar CAs.

\section{Synthesis}

The synthetic procedure suggested by us $\left[{ }^{19}\right]$ is easier than that of Charlionet et al. Technical mixtures of PEPAs (usually applied for epoxyresin hardening) or technical TETA or TEPA are distilled under vacuo to give a pale yellow product. A calculated amount of purified BIS («Reanal», Hungary) is dissolved in warm $\left(40^{\circ} \mathrm{C}\right.$ or more, if necessary) $25 \%$ water solution of purified PEPA with stirring to give PEPA:BIS ratio $2: 1$. After centrifugation at $5 \cdot 10^{3} \mathrm{~g}$ for 30 minutes the supernatant is carefully mixed with freshly distilled acrylic acid («Reachim», USSR). Since some of PEPA molecules are involved in the precipitant, the correct amount of acrylic acid is controlled by measuring the $\mathrm{pH}$ of probes $\left(1 \mathrm{ml}\right.$ of probe $+10 \mathrm{ml} \mathrm{H} \mathrm{H}_{2} \mathrm{O}$ ). The right proportion of ingredients for «neutral» CAs occurs at $\mathrm{pH}$ from 7.8 to 8.2 (Fig. 3 ). When synthesizing «acidic» or «basic» CAs, the reagent proportion should be another one and $\mathrm{pHs}$ have to be 6.0 and 9.5 , respectively. The mixture is then degassed and heated under inert athmosphere at $70^{\circ} \mathrm{C}$ for $12-15$ hours.

Care should be taken to avoid a contact with air of ingredients and product, especially when they are hot. Coloured admixtures could be removed on charcoal as described by Vinogradov et al. [5]. But it is not necessary when one does not use UV detection of proteins, for instance, in case of analytical IEF on polyacrylamide gel plates with staining of protein zones by Coomassie Blue or other specific reagents, or in preparative separation in granulated gels as described by Radola [21]. Focusing was performed on LKB Multiphor 2117 on polyacrylamide gel plates with different proteins from snake poisons. Solution for polymerization were (all reactives received from «Reanal», Hungary): Solution $A$ : $13 \mathrm{ml}$ of $3.9 \mathrm{~g}$ acrylamide and $0.13 \mathrm{~g}$ of BIS; Solution 


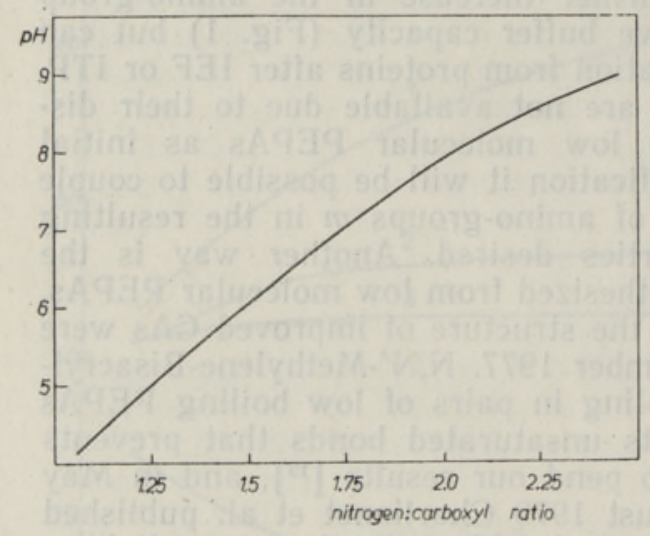

Fig. 3. Dependence of $\mathrm{pH}$ of the ingredients mixture on reagent proportion $M / I$. pH does not considerably change completion of the reaction.

B: $4 \mathrm{ml}$ of CAs, $7.5 \mathrm{~g}$ of sucrose and $0.1 \mathrm{ml}$ of tetramethylenediamine diluted to $46 \mathrm{ml}$ by deionized water; Solution $C: 0.05 \mathrm{~g}$ of ammonium persulphate in $5 \mathrm{ml}$ of deionized water. $A$ and $B$ solutions are mixed, filtered, deaerated for 5 minutes and $1 \mathrm{ml}$ of solution $C$ is added to polymerize the gel for 20 to 200 minutes. IEF is performed under conditions usually used for LKB Ampholines $\left[{ }^{22}\right]$. pH gradient was measured with antimony-antimony oxide surface electrode $\left(\left[{ }^{23}\right]\right.$, «home-made») with calomel reference electrode. $1 \times 1 \mathrm{~cm}$ slices are cut from one side of plate, weighed and placed in $10 \mathrm{ml}$ of deionized water for 10 hours. Conductivity is measured by conductometer OK - 102/1 (Hungary). Parallel slices are examined for buffer capacity by automatic titration apparatus (BAT-15, USSR) as described by Fredriksson $\left[{ }^{17}\right]$. Focussed protein zones are obtained as recommended [22]. Parallel experiments are run with wide $\mathrm{pH}$ range «Ampholine» and «Servalyt».

\section{Results}

We were not able to obtain good photos for reproduction in this paper, but observations show that the resolving power of our CAs is the same (or even better) as that of commercial ones. Some commercial plates, after focusing, gave slightly coloured stripes in the neutral $\mathrm{pH}$ zone while our CA plates were free from this drawback.

Figs 4 and 5 represent buffer capacity and conductivity of the new CAs and show that these properties are better than those of commercial samples.

The molecular weight distribution of CAs synthesized from TETA, BIS, and acrylic acid is obtained by gel filtration on Sephad-

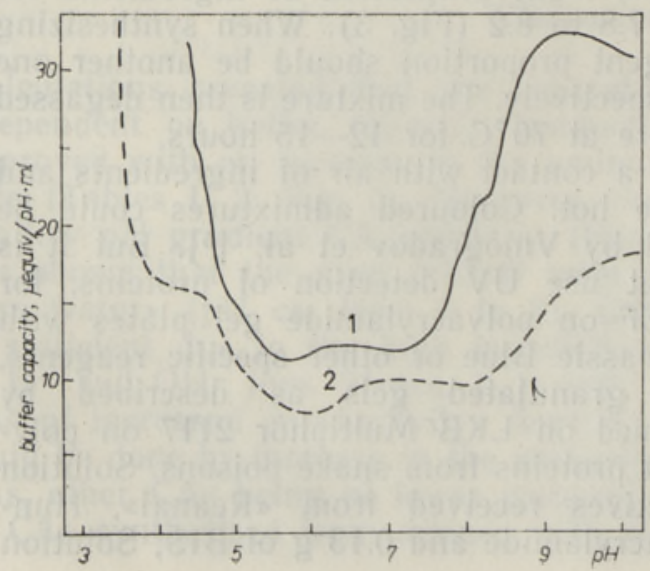
ex G-25 Superfine («Pharmacia», Sweden) and is represented in Fig. 6.

However, it is impossible to obtain good $\mathrm{pH}$ gradients with these CAs lower than $\mathrm{pH}=3.5$ and higher than $\mathrm{pH}=9.5$. Special synthesis is needed, including coupling of sulphuric or phosphoric acid residues and quaterni-

Fig. 4. Buffer capacity of focused CAs. 1 - new CAs, 2 - «Servalyt T $4-9$. 


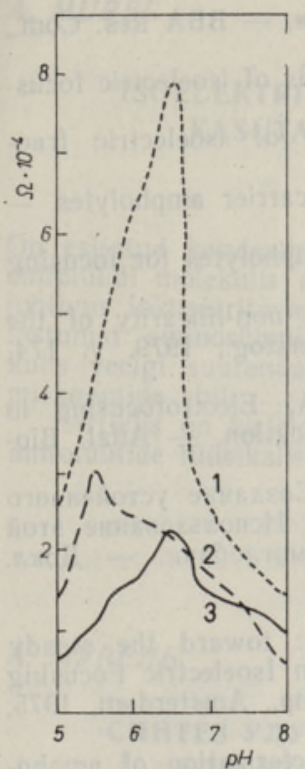

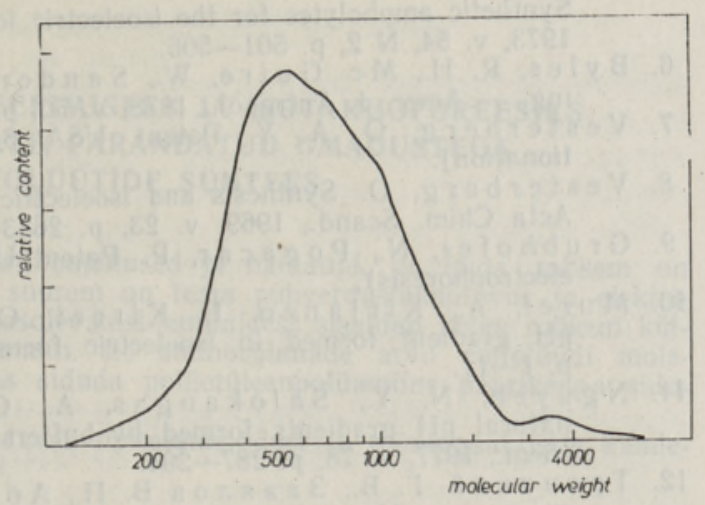

Fig. 6. Molecular weight distribution of the new TETA.BIS CAs.

Fig. 5. Conductivity of focused CAs in the neutral $\mathrm{pH}$ zone. 1 - TETA carrier ampholytes, 2 - PEHA CAs («Ampholine»), 3 - TETA.BIS CAs.

zation. This work is in progress as well as the fractionation of C.As in order to obtain shallow $\mathrm{pH}$ range CAs; results will be reported separately.

When BIS was applied after the coupling of acrylic acid to PEPA, the solution became solid with cooling to room temperature. Only after heating at $70^{\circ} \mathrm{C}$ for 5 hours the product was identical to those CAs described above. This gel formation can be explained as a formation of $\pi$-complex of unsaturated bonds of BIS with more than two PEPA molecules to provide space fixation of ingredients.

\section{Conclusion}

Improvement of buffer capacity, conductivity and increase in isomers number with an increase in the amino-group content in one CA molecule is shown. Low boiling TETA and TEPA provide a simple and inexpensive procedure of CA synthesis involving BIS for coupling PEPA molecules in pairs. The low cost of such CAs can simulate a wide application of preparative scale IEF and ITP.

\section{REFERENCES}

1. F a w cett, J. S. Some recent development in preparative isoelectric focusing. In: Arbuthnott, J. P. et al. (Eds). Isoelectric Focusing, New York-London-Paris, 1975 , p. $23-43$.

2. C a s pers, M. L., P o sey, Y., Brown, R. K. Separator isoelectric focusing: An improved method of protein analysis and purification. - Anal. Biochem., 1977 , v. 79 , p. $166-180$.

3. Righetit, P. G., Chillemi, F. Isoelectric focusing of peptides. - J. Chromatog., 1978 , v. 157 , p. $243-251$.

4. Righetti, P. G., Pagani, M., Gianazza, E. Characterization of synthetic carrier ampholytes for isoelectric focusing. - J. Chromatog., 1975, v. 109, p. $3411-356$.

5. Vinogradov, S. N., Lowenkron, S., Andonian, M. R., Bagshaw, J. 
Synthetic ampholytes for the isoelectric focusing of proteins. - BBA Res. Com., 1973 , v. 54 , N 2 , p. $501-506$.

6. Byles, R. H., Mc Guire, W., S anders, M. F. Methods of isoelectric focusing. - Amer. J. Antropol., 1978, v. 50, p. 27-34.

7. Vesterberg, O. A. Y. Patent USA 3.485.736 (Method of isoelectric fractionation).

8. Vesiterberg, O. Synthesis and isoelectric fractionation of carrier ampholytes. Acta Chim. Scand., 1969 , v. 23, p. 2653-2666.

9. Grubhofer, N., Pogacar, P. Patent USA 3.770.603 (Ampholytes for focusing electrophoresis).

10. Murel, A., Kirjanen, I., Kirret, O. Instability and non-linearity of the $\mathrm{pH}$ gradient formed in isoelectric focusing. - J. Chromatog., 1979, v. 174, p. $1-11$.

11. Nguyen, N. Y., S a lokangas, A., Chrambach, A. Electrofocusing in natural $\mathrm{pH}$ gradients formed by buffers: Gradient modification. - Anal. Biochem., 1977 , v. 78 , p. $287-294$.

12. Т ро ицкий Г. В., З а в ялов В. П., А бра мов В. М. Создание устойчивого градиента рН в смеси буферный раствор-неэлектролит. Использование этой системы для изоэлектрофокусирования альбумина и гемоглобина. - Докл. AH CCCP, 1974 , т. 214 , с. $955-958$.

13. Решетов П. Д. Personal communications.

14. Catsimpoolas, N. Transient state isoelectric focusing: toward the steady state and beyond. - In: Righetti, P. G. (Ed.) Progress in Isoelectric Focusing and Isotachophoresis. P. G. North-Holland Publishing Comp., Amsterdam, 1975, p. $77-92$.

15. Svensson, H. Isoelectric fractionation, analysis and characterization of ampholytes in natural $\mathrm{pH}$ gradients. I. The differential equation of solute concentration at a steady state and its solution for simple cases. - Acta Chim. Scand., 1961 , v. 15 , p. $325-341$.

16. Svensson, H. Isoelectric fractionation, analysis and characterization of ampholytes in natural $\mathrm{pH}$ gradients. II. Buffer capacity and conductance of isoionic ampholytes. - Acta Chim. Scand., 1962, v. 16, p. 456- 466.

17. Fredriksson, S. Comparison of the buffer capacities of Ampholine and Serva1yt. Carrier ampholyte systems used in isoelectric focusing. - J. Chromatog., 1977 , v. 135 , p. $441-446$.

18. Rible, H. Isoelectric fractionation, analysis and characterization of ampholytes in natural $\mathrm{pH}$ gradients. II. Buffer capacity and conductance of isoionic ampholytes. A correction. - Acta Chim. Scand., 1971, v. 25, p. 2768-2769,

19. Мурель А., Си игур Ю. Синтетический амфолит-носитель для разделения биополимеров методами изоэлектрофокусирования и изотахофореза. - Авт. заявка $2770103 / 2305,30$ мая 1979 г.

20. Charlionet, R., Martin, J. P., Sesboüé, R., M a dec, P. J., Le feb. $\mathrm{vre}, \mathrm{F}$. Synthesis of highly diversified carrier ampholytes. Evaluation of the resolving power of isoelectric focusing in the $\mathrm{Pi}$ system (Alpha-1-antitrypsin genetic polymorphism). - J. Chromatog., 1979 , v. 176, p. $89-101$.

21. Radola, B. J. Isoelectric focusing in layers of granulated gels. I. Thin-layer isoelectric focusing of peptides. - BBA, 1973, v. 295, p. 412-428.

22. LKB application note No 75. LKB 2117 Multiphor-1. Analytical thin layer gel electrofocusing in polyacrylamide gel.

23. Beeley, J. A., Stevensob, S. M., Beeley, J. G. Polyacrylamide gel isoeleotric focusing of proteins: Determination of isoelectric points using an antimony electrode. - BBA, 1972 , v. 285 , p. 293-300.

Academy of Sciences of the Estonian SSR, Institute of Chemistry

Received

Apr. 2, 1980 
A. MUREL

\section{ISOELEKTRILISEKS FOKUSEERIMISEKS JA ISOTAHHOFOREESIKS KASUTATAVATE ODAVATE, PARANDATUD OMADUSTEGA KANDEAMFOLUUTIDE SUNTEES}

On esitatud kandeamfolüütide soovitavad omadused ja näidatud, et mida rohkem on amfolüüdi molekulis aminorühmi, seda suurem on tema puhverdusmahutavus ja elektrijuhtivus fokuseeritavas süsteemis. Olemasolevatest amiinidest sisaldab kõige rohkem küllastunud aminorühmi pentaetüleenheksamiin. Et aminorühmade arvu amfolüüdi molekulis veelgi suurendada, on otstarbekas siduda polüetüleenpolüamiine paarikaupa sidumisagentide abil.

Artiklis on kirjeldatud lihtsat ja odavat sünteesimoodust ja mōningaid uute kandeamfolüütide füüsikalis-keemilisi omadusi.

\section{A. МУРЕЛЬ}

\section{СИНТЕЗ УЛУЧШЕННЫХ И НЕДОРОГИХ АМФОЛИТОВ-НОСИТЕЛЕИ ДЛЯ ИЗОЭЛЕКТРОФОКУСИРОВАНИЯ И ИЗОТАХОФОРЕЗА}

Представлены теоретические требования, предъявляемые $\mathrm{k}$ структуре улучшенных амфолитов-носителей. Показано, что чем больше содержание аминогрупп в одной молекуле амфолита, тем выше его буферная емкость и электропроводность в фокусируемой системе. Из доступных аминов наиболее насыщен аминогруппами пентаэтиленгексамин, и дальнейшее увеличение содержания аминогруп в молекуле амфолитаносителя достигается попарным связыванием полиэтиленполиаминов сшиваюими агентами.

Описаны простой и недорогой способ синтеза амфолитов-носителей и некоторые физико-химические свойства новых амфолитов-носителей. 